\title{
Teachers' and Students' Perceptions of the Socio- Scientific Issues (SSI)-based Electronic Student Worksheets for Improving Scientific Literacy and Collaboration Skills
}

\author{
Dwi Septiawati $^{1}$, Sunyono $^{2}$, Dewi Lengkana ${ }^{3}$ \\ \{septiawatidwi@gmail.com ${ }^{1}$, sunyono_ms@yahoo.com ${ }^{2}$, dewilengkana76@gmail.com ${ }^{3}$ \} \\ Science Education, Master Program, Lampung University, Indonesia ${ }^{1}$, Chemistry Education, \\ Lampung University, Indonesia ${ }^{2}$, Biology Education, Lampung University, Indonesia ${ }^{3}$
}

\begin{abstract}
This study aims to improve students' literacy skills and scientific collaboration in learning using SSI-based electronic student worksheets. The method used in this research is the descriptive method. The study population was one teacher and one hundred students each from ten secondary schools. Data collection involves a questionnaire with percentages. The results of this study provide an understanding that teachers' perceptions of learning using SSI-based electronic worksheets at the implementation level are still in the very low category because teachers still prefer conventional worksheets and books. Teachers' perceptions seen from the perspective of scientific literacy are still categorized as "low", but at least teachers have tried to involve them in learning activities. The teacher's perception of student collaboration skills is in a low category too. Likewise, students' perceptions of learning involving SSI-based electronic worksheets for scientific literacy and collaboration skills were also categorized as "very low". On the other hand, the percentage of students who need SSI-based electronic student worksheets in learning is in the high category. Considering the results, it is acceptable to conclude that the use of SSIbased electronic student worksheets in learning is very important for the improvement of students' scientific literacy and collaboration skills.
\end{abstract}

Keywords: SSI, electronic student worksheets, electronic student worksheets, scientific literacy and collaboration skills.

\section{Introduction}

The twenty-first century is an industrialization and globalization era, which is marked by the high pace of technological development and the spread of information, which affects every aspect of life. The high pace of the development and spread is in line with the challenges to be faced, in which case the challenges rising to the surface are getting more and more complex, and human resources able to deal with such challenges are of paramount importance. Quality human resources can be formed out of the roles of education. The mastery of science and technology (known as IPTEK (Ilmu Pengetahuan dan Teknologi) in Indonesian) holds the key role in the development of learners' personal skills in the field of science and technology [1]. For the sake of personal, social, economic and environmental interests, learners need to be equipped with adequate competence so as to be active participants in their society [2] so that they will be able to solve problems and beat challenges in life. 
The essence of science learning is the learning in the forms of processes, knowledge and products. Technology is a vivid example of scientific products, and it should be feasible to use science to solve problems in daily life. In order that learners can solve their problems, they should have scientific literacy. Scientific literacy affects learners in making a decision, either a personal or group decision. In relation to the abovementioned case, the learning based on the 2013 curriculum focuses on scientific literacy achievements in relation to solving social issues globally. It is a form of learning in accordance with the essence of scientific learning, which not only focuses on the acquisition and retention of knowledge, but also on the scientific processes and attitude. Nowadays, one of the applicable learning strategies for achieving scientific literacy for learners is Socio-Scientific Issues (SSI), which is a learning strategy whose goal is to stimulate intellectual, moral, and ethical development, along with the awareness of the relationship between science and social life.

Problem solving requires a group discussion (team-building) in which the participants take into consideration different perspectives and fully participate in the talk of the topic till they reach an agreement as the solution to the problem or the process of making a decision. The term team building is known as collaboration these days. The term collaboration means more than just cooperation. It means learning to design while working together as a team, taking different perspectives into account, and taking part in a certain topic by contributing as much as possible, listening to and supporting the others [3]. As technological development advances, collaboration skills are spotlighted by researchers. Collaboration is a process in which two persons or more work together for a certain purpose through face-to-face interaction [4]. The interaction can actually be made directly or indirectly via internet-based communications, which are also known as e-tools, such as emails, blogs, and wikis. Such indirect communication can increase digital interaction between two persons or more while they are seeking a mutual agreement as the solution to a problem or a process of making a decision.

The intention of improving learners' science literacy and collaboration skills, the learning involving the e-tool electronic student worksheets is applied. The results of several previous studies demonstrate that the use of such a learning medium as the electronic student worksheets is an option for improving learners' studying mastery, high-order thinking skills, and learning outcomes, and for increasing their interest [5],[6]. Unfortunately, the survey carried out by The Trends in International Mathematics and Science Study (TIMSS) in 2015 revealed that Indonesia ranked forty-sixth in a group of 51, with an average of 397 for science mastery. It is not the only reference in the form of a survey. Another survey, carried out by Programme for International Student Assessment (PISA) in the same year, which was on science mastery as well, enlisted Indonesia as a country with a point of 403. In 2018, Indonesia's score for this matter even shrunk into 396. It caused Indonesia to rank seventieth in a group of 78 . With all that in mind, this research was aimed at figuring out teachers' and students' perceptions of the socio-scientific issues (SSI)-based electronic student worksheets for improving scientific literacy and collaboration skills.

\section{Methodology}

This research was conducted in November 2019 on ten junior high schools, with a sample of 10 teachers and 100 students. The method applied in this research was a descriptive method in the form of a survey, which described what took place in the process of using the electronic student worksheets to improve students' literacy and collaboration skills. This research is 
underlain by qualitative data obtained from a questionnaire. The data was analysed by way of manual scoring system. A ticked item means that the respondent agreed to the statement. The percentage of each item was calculated with the formula [7] and the criteria are presented according to [8].

Tabel 1. Percentage Interpretations of the Questionnaire.

\begin{tabular}{cl}
\hline Percentage & \multicolumn{1}{c}{ Criteria } \\
\hline $80,1-100,0$ & Very High \\
$60,1-80,0$ & High \\
$40,1-60,0$ & Medium \\
$20,1-40,0$ & Low \\
$0,0-20,0$ & Very Low \\
\hline
\end{tabular}

\section{Results and Discussion}

The results of the data analysis in this research suggest that in general, the use of the electronic student worksheets in the learning activities was not yet applied, as seen in Table 2 .

Table 2. The Teachers' Perceptions of the Socio-Scientific Issues (SSI)-based Electronic Student Worksheets.

\begin{tabular}{clcc}
\hline No & \multicolumn{1}{c}{ Statements } & $\begin{array}{c}\text { Yes } \\
(\boldsymbol{\%})\end{array}$ & $\begin{array}{c}\text { No } \\
(\mathbf{\%})\end{array}$ \\
\hline 1 & The school has a computer lab & 100 & 0 \\
2 & The school is facilitated with Wi-Fi/ Hotspot & 60 & 40 \\
3 & Using media in the learning for better understanding & 30 & 70 \\
4 & Using media in the learning to improve scientific literacy & 10 & 90 \\
5 & Using teaching material for improving collaboration skills in the learning & 40 & 60 \\
6 & $\begin{array}{l}\text { Good students' responses to frequently used science teaching material } \\
\text { (conventional student worksheets) }\end{array}$ & 50 & 50 \\
7 & $\begin{array}{l}\text { Using the socio-scientific issues (SSI)-based electronic student worksheets in } \\
\text { the learning activities. }\end{array}$ & 0 & 100 \\
8 & $\begin{array}{l}\text { The socio-scientific issues (SSI)-based electronic student worksheets } \\
\text { accompanied by questions directing students to scientific literacy skills }\end{array}$ & 0 & 90 \\
9 & $\begin{array}{l}\text { The socio-scientific issues (SSI)-based electronic student worksheets } \\
\text { accompanied by questions directing collaboration skills }\end{array}$ & 0 & 100 \\
10 & $\begin{array}{l}\text { The need of the socio-scientific issues (SSI)-based electronic student } \\
\text { worksheets in learning activities for improving scientific literacy }\end{array}$ & 100 & 0 \\
\hline & $\quad$ Avarage & $\mathbf{3 9}$ & $\mathbf{6 1}$ \\
\hline
\end{tabular}

In reference to Table 2, in which the yes and no answers for each statement have a significant difference in between, the teachers did not use the socio-scientific issues (SSI)-based electronic student worksheets in the learning activities so that it can be categorized as "very low" and the percentage of directing students to scientific literacy skills is also still "very low", yet the percentage of directing students to collaboration skills is just "low". 
Table 3. The Students' Perceptions of the Socio-Scientific Issues (SSI)-based Electronic Student Worksheets.

\begin{tabular}{clcc}
\hline No & \multicolumn{1}{c}{ Statements } & $\begin{array}{c}\text { Yes } \\
(\mathbf{\%})\end{array}$ & $\begin{array}{c}\text { No } \\
(\mathbf{\%})\end{array}$ \\
\hline 1 & The teacher uses the computer lab for scientific learning & 5 & 95 \\
2 & The school is facilitated with Wi-Fi/ Hotspot & 60 & 40 \\
3 & Lecturing is the teacher's only method & 50 & 50 \\
4 & The teacher relates the learning to the environment & 60 & 40 \\
5 & The media used in the learning are only textbooks and student worksheets & 80 & 20 \\
& from the designated publishers & 40 & 60 \\
6 & The media used in the learning give chances to investigation & 80 & 20 \\
7 & Able to accept reasons and assumptions from friends & 90 & 10 \\
8 & $\begin{array}{l}\text { Agree to the learning using the socio-scientific issues (SSI)-based electronic } \\
\text { student worksheets to train students' ability to put forward questions and } \\
\text { argue }\end{array}$ & $\mathbf{5 8}$ & $\mathbf{4 2}$ \\
\hline
\end{tabular}

As shown in Table 3, there is a significant difference as well between the yes and no answers to each statement. Most students, with the category "Very High", answered "no" for the statement about the use of the computer lab for scientific learning, in this case, in terms of the use of electronic student worksheets. Their answers to this statement were in line with those of the teachers, who mostly answered "no", with the category "Very High", to the statement about using electronic student worksheets for scientific learning. The following is Table 4, which provides the information concerning the perceptions of collaboration skills.

Table 4. Perceptions of Collaboration Skills.

\begin{tabular}{|c|c|c|c|c|c|c|}
\hline No & $\begin{array}{l}\text { Statements } \\
\text { (Teachers) }\end{array}$ & $\begin{array}{c}\text { Yes } \\
\%\end{array}$ & $\begin{array}{l}\text { No } \\
\% \\
\end{array}$ & $\begin{array}{c}\text { Statements } \\
\text { (Students) }\end{array}$ & $\begin{array}{l}\text { Yes } \\
\% \\
\end{array}$ & $\begin{array}{c}\text { No } \\
\%\end{array}$ \\
\hline 1 & $\begin{array}{l}\text { The strategies applied by the } \\
\text { teacher can help students }\end{array}$ & 50 & 50 & $\begin{array}{l}\text { The teacher has trained students } \\
\text { to be engaged in social issue- } \\
\text { based learning }\end{array}$ & 50 & 50 \\
\hline 2 & $\begin{array}{l}\text { The teacher has involved } \\
\text { media to help students } \\
\text { understand Science }\end{array}$ & 80 & 20 & $\begin{array}{l}\text { The teacher has trained students } \\
\text { to be engaged in problem solving } \\
\text { with their friends }\end{array}$ & 20 & 60 \\
\hline 3 & $\begin{array}{l}\text { The teacher has trained } \\
\text { students to work } \\
\text { collaboratively }\end{array}$ & 40 & 80 & $\begin{array}{l}\text { The teacher has given a } \\
\text { questionnaire for measuring } \\
\text { collaboration skills }\end{array}$ & 0 & 100 \\
\hline 4 & $\begin{array}{l}\text { The teacher has given a } \\
\text { questionnaire for measuring } \\
\text { collaboration skills }\end{array}$ & 0 & 100 & & & \\
\hline & Average & 42 & 58 & & 23 & 77 \\
\hline
\end{tabular}

In consideration of Table 4 , it is safe to say that the teachers had never measured the students' collaboration skills. Table 4 also demonstrates that the teachers' perceptions of training students to work collaboratively still fell into the category "Medium", and it is in line with the students' perceptions that the teachers had trained them to work collaboratively, but had not trained them to be engaged in problem solving with their friends. The percentage is $60 \%$. The following section contains the discussion of the previous findings in relevance to the results of this research. 


\subsection{Teachers' Perceptions of the Use of Electronic Student Worksheets in Improving Scientific Literacy}

In consideration of the data in Table 2, it is plausible to infer that most schools have computer labs as learning facilities. Most of them are also equipped with Wi-Fi/ Hotspot for the sake of better learning in the labs. The use of computer labs as learning facilities potentially contributes to educational advancement a great deal in the globalization era. The involvement of digital technology plays an important role in supporting and improving learners' cognitive processes and thinking skills [9]. The learning involving technology is also able to change the learning atmosphere dominated by the teacher, or teacher-centered learning, with the method of lecturing into the learning atmosphere centering on students, or student-centered learning, so that it is effective in enhancing scientific literacy. The scientific literacy itself serves its role by affecting learners' decision-making, either personal or group decision-making [10]. The importance, besides decision-making, also concerns learners' intelligence quotients, creative thinking, problem solving, and high-order thinking skills. Yet, due to the demand that a teacher must give all the material to the learners within a designated period of time [11], teachers have to act as sources of learning. As for the learning media used by them, they are limited to textbooks and student worksheets from designated publishers, which mostly do not yet train learners' comprehension and scientific literacy skills, as shown in Table 2, with $10 \%$ for the answers "yes" in a row. However, there were still a few teachers who had applied PowerPoint (PPT) in their teaching and learning activities, so the students' responses were quite good, with $50 \%$.

The use of PPT as a medium in learning activities was actually a good start, but a a lot of teachers had not made use of electronic student worksheets as learning media. Referring to Table 2 , only $10 \%$ of the answers were "yes" and $90 \%$, the rest, were "no", so the use of electronic student worksheets was categorized into "Very Low" and as a result, the role of electronic student worksheets in enhancing scientific literacy had still been invisible. The data shown by the table implies that the teachers perceived electronic student worksheets as beneficial to the learning in terms of the improvement on scientific literacy, which would in turn increase the students' interest and improve their learning outcomes [12],[13].

\subsection{Students' Perceptions of the Use of Electronic Student Worksheets in Improving Scientific Literacy}

Not much different from the teachers' perceptions of the use of electronic student worksheets, the use of computer labs for scientific learning was just 5\% and it was categorized as "very low". However, with regard to the teachers' teaching with the method of lecturing, the yes and no answers were equal in percentage, $50 \%$. It resulted from the fact that some teachers had put to the test learning models in learning activities. The models were called inquiry and discovery learning. The media used in the learning were textbooks and student worksheets from the designated publishers. However, a small number of teachers decided to create their own student worksheets. It is what the percentages of the yes and no answers imply, $80 \%$ belonged to the former, $20 \%$ to the latter. As a result, the students did not have any chances to investigate by themselves and be engaged in a discussion despite the fact that they were able to accept reasons and assumptions from their friends. This can be seen from the percentage of 90 for the yes answer and it fell into the very high category. Learning all that, it is known that $90 \%$ of the students were in agreement that the idea of using electronic student worksheets to improve scientific literacy should be put into practice. 


\subsection{Teachers' and Students' Perceptions of Collaboration Skills}

Collaboration is more than just cooperation. It covers designing, working together, taking different perspectives into consideration, and taking part in a certain topic by making a contribution, listening to and supporting the others in figuring out the solutions to various problems in real life [14]. As shown by Table 4, the teachers had never measured the students' collaboration skills. Nevertheless, it can also be seen that the teachers had trained one of the collaboration skills, which was working together, but the process did not yet cover training them in their engagement in seeking prospective solutions on the basis of the existent social issues.

\section{Conclusion}

The conclusion drawn from this research is that teachers have not yet made use of the socioscientific issues (SSI)-based electronic student worksheets in learning in order to improve scientific literacy $(100 \%)$, teachers have not yet measured collaboration skills $(100 \%)$, and teachers along with learners agree to the idea of making use of electronic student worksheets in learning as an effort to make improvements on scientific literacy $(100 \%)$.

Acknowledgments. We would lile to extend our sincerest, deepest and warmest grattitude to our beloved dependable advisors for the priceless guidance on this research, whose tittle is Teacher's and Students's Perceptions of the Socio Scientific Issues (SSI)-based Electronic Student Worksheet for Improving Scientific Literacy and Collaboration Skill. We are, without a shadow of a doubt, as thankful to everyone else involved in this research.

\section{References}

[1] Arifin, M. Common Textbook: Strategi Belajar Mengajar Kimia. JICA IMSTEP. 2013.

[2] Holbrook, J., and Rannikmae, M. The Meaning of Scientific Literacy. International Journal of Environmental and Science Education. 2009. Vol 4, No 3, pp 275-288.

[3] Sadler, T.D. and Zeidler, D.L. The morality of sosioscientific Issues:Construal and resulution on genetic engineering dilemmas. Journal of Science Education. 2004. Vol 88. pp 4-27.

[4] Bellanca, J., and Terry, S. Classroom Without Borders: Using Internet Project to Teach Communication and Collaboration. New York: Teachers College. Collumbia University. 2011.

[5] Annafi, N., Ashadi, \& Mulyani, S. Pengembangan Lembar Kegiatan Peserta Didik Berbasis Inkuiri Terbimbing Pada Materi Termokimia Kelas Xi SMA/MA. Jurnal Inkuiri. 2015.Vol 4 No 1, pp 2128.

[6] Riyadi, B. Pengembangan e-lkpd dengan kvisoft flipbook maker berbasis guided inquiry pada materi fluida statis untuk menumbuhkan high order thingking skills. Tesis. Universitas Lampung. Lampung. 2018.

[7] Sudjana, N. Metode Statistika. Transito. Bandung. 2005.

[8] Arikunto, S. Dasar-Dasar Evaluasi Pendidikan. Bumi Aksara: Jakarta. 2008.

[9] Selwyn, neil. Education and Technology Key Issues and Debats. India: Replika press Pvt. 2011.

[10] Lederman, N. G., Lederman, J. S. and Antink, A. Nature of science and scientificinquiry as contexts for the learning of science and achievement of scientific literacy. International Journal of Education in Mathematics, Science and Technology. 2013. Vol. 1, Pp 138-147.

[11] Fitriyah. Pengaruh Model Pembelajaran Discovery Learning Terhada Hasil Belajar Matematika Siswa SMA MAN Model Kota Jambi. STKIP PGRI Sumatra Barat. Jambi. 2017. 
[12] Dharma. Pengembangan Media Pembelajaran Multimedia Interaktif Untuk Meningkatkan Minat dan Hasil Belajar Peserta didik (Studi Pengembangan di SMP Pasundan 1 Bandung). Tesis. Pendidikan Kewarganegaraan, Universitas Pendidikan Indonesia. 2012.

[13] Yusrizal. Penggunaan multimedia dalam pembelajaran untuk meningkatkan hasil belajar siswa. Tesis. SPS UPI Bandung: Tidak diterbitkan. 2008.

[14] Greenstein, L. Assessing 21 st Century Skill: A Guide to Evaluating Mastery and Authentic Learning. United States of America: Corwin A Sage Company. 2012. 